\title{
ICT for Psychosocial Competence Development among Adolescents
}

\author{
M.A.D.A.L Mudannayake ${ }^{1}$ and T.A. Weerasinghe ${ }^{1}$ \\ ${ }^{1}$ University of Colombo School of Computing, Sri Lanka
}

\begin{abstract}
Along with the technology development, teenagers get more freedom and opportunities to experience new things and people. As a result teenagers are more vulnerable for abuse and health problems in particularly for teenage pregnancy. In order to minimize this issue Health Organizations have started conducting workshops with the intention of empowering teenagers with knowledge, attitude and safety skills required to prevent pregnancy. However, teenagers seem reluctant to show their interest for studying about sexuality and talk about their issues openly. Therefore, health organizations emphasize the importance of identifying an innovative and personalized strategy to develop psychosocial competencies in teenagers. Since information and communication technology has proven to bring benefits for education, the present study investigated how ICT can be used to reduce the major health problem, teenage pregnancy through psychosocial competence development among teenagers. The study consisted of a literature review and two focus group interviews. The findings imply that video, game and discussion are considered as suitable instructional methods to deliver eLearning content in an effective way. Based on the findings this paper discusses how ICT based interventions should be designed to support adolescents to develop their psychosocial competencies.
\end{abstract}

Keywords: Psychosocial competency, Teenage pregnancy

\section{Introduction}

Teenagers are the most valuable asset in a country. About one fifth (1/5) of world population are teenagers [2]. However, according to World Health Organization (WHO) hundreds of teenagers get infected with HIV every week [3] and according to the United Nations Populations Fund [1] adolescents have experience in limited and incomplete knowledge on sexual and reproductive health, a small percentage of adolescents have experienced pre marital sex, unprotected sex with sex workers and about $6 \%$ of adolescent girls in ages between 15-19 had a baby or were pregnant. Therefore health organizations [1] have taken initiatives to improve quality and access to youth friendly health programs and services. These initiatives aim to build health workforce capacity to effectively and efficiently respond youth health issues and to [4] expand and strengthen physical and mental health including sexual and reproductive health education of adolescents at school level. According to The United Nations Children's Fund (UNICEF) [8] psychosocial competencies are essential for adolescents to face challenges effectively that meet in their day to day life [1]. World Health Organization [1] has also state that psychosocial competencies and attitudes are more important than knowledge for adolescents to face day to day problems.

A study conducted by Botvin et al. [5], LaFromboise et al. [40] and Stein et al. [6] signifies that psychosocial competencies are a major component in reducing adolescents' health problems. Further the United Nations Populations Fund (UNFPA) [1] has identified that empowering psychosocial competencies as a behaviour change communication strategy in order to adopt and maintain the desirable behaviours among adolescents in the area of sexual and reproductive health. Based on their findings UNFPA [3] that use of ICT based intervention to develop psychosocial competencies among adolescents' will be more beneficial than a traditional intervention. ICT has rapidly been brought to use in various areas [8] including teaching and learning. Moreover, it has been globally accepted as a component of education. Online interventions can be accessed by all learners at the anytime irrespective of their locations. Also it will be a solution for the problem 
of addressing individual learning differences and time limitation to conduct the psychosocial competencies development programs at school level.

However, it is not clear how ICT should be used to develop psychosocial competencies in teenagers. Therefore present study aimed to answer "How can ICT be used to support development of psychosocial competencies in teenagers?".

\section{Methodology}

The study consisted of two major phases: a literature review and two focus group interviews. The literature review was conducted by analyzing more than fourty (40) research papers which included Twenty five (25) conference papers and Twelve (12) journal papers. Also we referred to several magazines and reports published by World Health Organization [3][2][4]. The papers and magazines were retrieved from Google Scholar, Science Direct, Web of Science, and ACM Digital library by using search text such as "teenage pregnancy" + ICT, "psychosocial competency development"+ ICT, "life skills" + ICT , "psychosocial competencies intervention" +ICT, "adolescents' reproductive health"+ ICT.

The content of the relevant research papers about interventions of proven effectiveness were further analyzed to find ICT based pedagogical approaches or technologies used to develop psychosocial competencies in teenagers.

The findings of this literature review were triangulated with two focus group interviews conducted with a group of female adolescents having regular contacts with the Ministry of Health Sri Lanka. The sample group consisted of 10 adolescents' ages between 15 and 19 and they were selected upon their consent for participating in the study.

The interviews were guided by a set of questions prepared based on the data gathered from professional student counsellors and some medical reports at the Ministry of Health, Sri Lanka. Prior to use, the questionnaire was reviewed by a professional counsellor and it was used to gather data at the interviews under his guidance. The data collected through the focus group interviews were analysed quantitatively and qualitatively.

\section{Analysis and Results}

The sample of papers collected for the literature review were analyzed and categorized based on different instructional methods and technologies used to develop ICT-based learning interventions (see Table 3.1).

Table 3.1: Instructional methods, technologies and examples

\begin{tabular}{lll}
\hline Instructional method & Technology & Example \\
\hline Video & Video sharing sites & Teensource.org [9] \\
\cline { 2 - 3 } & Vodcasts & The Midwest Teen Sex Show [10] \\
\hline Game & Online game & RePlay: Finding Zoe [11] \\
& & Serious digital games like Prepare, The Romance Game, \\
& SISTAS, and It's Your Game [12] \\
\hline Images and text & Web sites & Youthline at http://www.youthline.ca \\
& & QYouth Resource at http://qyouthresources.org/ \\
& & WebMD at http://www.webmd.com \\
& & Sex,etc at https://sexetc.org/ \\
\hline Audio & Podcasts & Sex Really: The Show [13]
\end{tabular}


Podcasts at CDC [9]

Planned Parenthood Online's Speaking of Sex [14]

$\begin{array}{lll}\text { Discussion (Q\&A) } & \begin{array}{l}\text { Short Message Service } \\ \text { (SMS) technology }\end{array} & \text { Mobile for Reproductive Health (m4RH) [15] } \\ & \text { SexINFO [16] } \\ & \text { Hookup [17] }\end{array}$

\begin{tabular}{ll}
\hline Web-based social & Health promoting activities using MySpace, Facebook, \\
networking sites (SnSs) & Twitter
\end{tabular}

The above described primary analysis of literature implied that there are five main technologies mostly used for developing psychosocial competencies in adolescents. They are SMS technology, SnSs, video-sharing web sites, podcasts and online games. These technologies have been mostly used to deliver instructions based on discussion, video, audio and games.

The literature reporting about these technologies were further analyzed to identify the most suitable technology that can be used to develop an intervention aiming to support development of psychosocial competencies in adolescents. The findings of this further analysis are showing in Table 3.2.

Table 3.2: Comparison of instructional methods and technologies

\begin{tabular}{l|l|l|l|l|l}
\hline $\begin{array}{l}\text { Instructional } \\
\text { method }\end{array}$ & $\begin{array}{l}\text { Technolo } \\
\text { gies }\end{array}$ & SnSs & Video & Audio & Game \\
\hline Discussion & SMS & $\begin{array}{l}\text { Sideo sharing } \\
\text { sites } \\
\text { that SnSs is more } \\
\text { efficient than } \\
\text { SMS in } \\
\text { reproductive } \\
\text { health education } \\
\text { among } \\
\text { adolescents[21] }\end{array}$ & $\begin{array}{l}\text { Podcasts } \\
\text { showed that } \\
\text { 57\% of online } \\
\text { adolescents } \\
\text { watched the } \\
\text { videos posted } \\
\text { on the video } \\
\text { sharing sites } \\
\text { and stated that } \\
\text { this is } \\
\text { effective than } \\
\text { text messaging } \\
\text { to deliver } \\
\text { reproductive } \\
\text { health } \\
\text { education [23] } \\
\text { [22] } \\
\text { for reproductive health } \\
\text { education [24] }\end{array}$ & $\begin{array}{l}\text { adolescent boys and } \\
\text { 94\% of adolescent } \\
\text { girls like to play } \\
\text { online games than } \\
\text { using text messages } \\
\text { [35][26]. }\end{array}$ \\
\hline
\end{tabular}




\begin{tabular}{|c|c|c|c|c|c|}
\hline & SnSs & 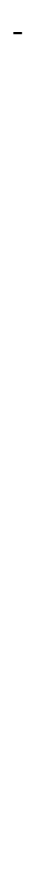 & $\begin{array}{l}\text { As videos can } \\
\text { be shared } \\
\text { using } \mathrm{SnSs} \text {, } \\
\text { the } \mathrm{SnSs} \text { are } \\
\text { more effective } \\
\text { than video } \\
\text { only sharing } \\
\text { sites for } \\
\text { reproductive } \\
\text { health } \\
\text { education } \\
\text { [27] }\end{array}$ & $\begin{array}{l}\text { Interventions reported } \\
\text { that only } 19 \% \text { of } \\
\text { online adolescents } \\
\text { tends to download } \\
\text { podcasts and SnSs are } \\
\text { more effective for } \\
\text { reproductive health } \\
\text { education [28] }\end{array}$ & $\begin{array}{l}\text { Studies showed that } \\
\text { playing games over } \\
\text { and over again can } \\
\text { change adolescents' } \\
\text { behaviour [29] over } \\
\text { other technologies } \\
\text { and found } 65 \% \text { of } \\
\text { boys and } 35 \% \text { girls } \\
\text { play games daily } \\
\text { [30]. As well as } \\
\text { studies showed that } \\
\text { Most adolescents like } \\
\text { to play video/online } \\
\text { games for } \\
\text { reproductive health } \\
\text { education than using } \\
\text { other methods as it is } \\
\text { comfortable, personal } \\
\text { and interactive [31] }\end{array}$ \\
\hline Video & $\begin{array}{l}\text { Video } \\
\text { sharing } \\
\text { sites }\end{array}$ & - & - & $\begin{array}{l}\text { Studies showed that } \\
14 \% \text { of online } \\
\text { adolescents uploaded a } \\
\text { video file to a sharing } \\
\text { site and } 39 \% \text { of online } \\
\text { adolescents shared } \\
\text { their own artistic } \\
\text { creations on video } \\
\text { sharing sites like } \\
\text { YouTube than using } \\
\text { podcasts. Therefore } \\
\text { video sharing sites are } \\
\text { more efficient than } \\
\text { podcasts[32] [33] }\end{array}$ & $\begin{array}{l}\text { Studies showed that } \\
99 \% \text { of adolescent } \\
\text { boys and } 94 \% \text { of } \\
\text { adolescent girls like } \\
\text { to play online games } \\
\text { and only } 57 \% \text { of } \\
\text { online adolescents } \\
\text { watched the videos } \\
\text { posted on the video } \\
\text { sharing sites. } \\
\text { Therefore online } \\
\text { games are more } \\
\text { effective than video } \\
\text { sharing sites [34][35] }\end{array}$ \\
\hline Audio & Podcasts & - & - & - & $\begin{array}{l}\text { Studies showed that } \\
\text { online games are } \\
\text { more effective than } \\
\text { podcasts regarding to } \\
\text { Reproductive health } \\
\text { education as only } \\
19 \% \text { of online } \\
\text { adolescents tends to } \\
\text { use podcasts.[36] }\end{array}$ \\
\hline
\end{tabular}

The findings of the literature review implied that video, game and discussion were the most effective instructional methods to deliver an online content (See Table 3.2).

\section{Findings from the focus group discussion}

Further a focus group discussion was conducted with a group of female adolescents to know their perception regarding the instructional methods. $80 \%$ of them expressed their willingness to study through online games and all informed that they would like to learn through videos (see Table 4.1). 
Table 4.1: Preference for instructional methods

\begin{tabular}{|l|c|}
\hline Instructional & Preference \\
\hline Video & $100 \%$ \\
\hline Game & $80 \%$ \\
\hline Image and & $40 \%$ \\
\hline Audio & $30 \%$ \\
\hline Discussion & $100 \%$ \\
\hline
\end{tabular}

Based on the findings of the focus group interviews, an online learning intervention was designed to support adolescents to develop their psychosocial competencies.

\section{Implications for design of online platform}

The following flow charts (See Figure 4.1, 4.2 and 4.3) were designed to satisfy the requirements of the adolescents who wish to receive support or learn about psychosocial competencies online. The requirements were identified and the expected levels of interaction were determined and based on the finding of the focus group interviews.

Further an online questionnaire was given to the adolescents to verify the design decisions taken. Based on the marks, the sample of adolescents was grouped into three categories: beginner, intermediate, and expert. Beginners are the adolescents who scored marks less than $30 \%$ and experts are the adolescents who score more than $80 \%$. Intermediates scored in between $30 \%$ and $80 \%$ for the online questionnaire. These grouping levels were decided based on the information provided by the counselors at the Ministry of Health.

According to the information provided by the ministry, only the adolescents in the intermediate group should better be provided with an online learning content and adolescents who scored less than $30 \%$ should be immediately directed to a professional counselor for personal advice [1]. 
M.A.D.A.L Mudannayake and T.A. Weerasinghe/ICT for Psychosocial Competence Development.....

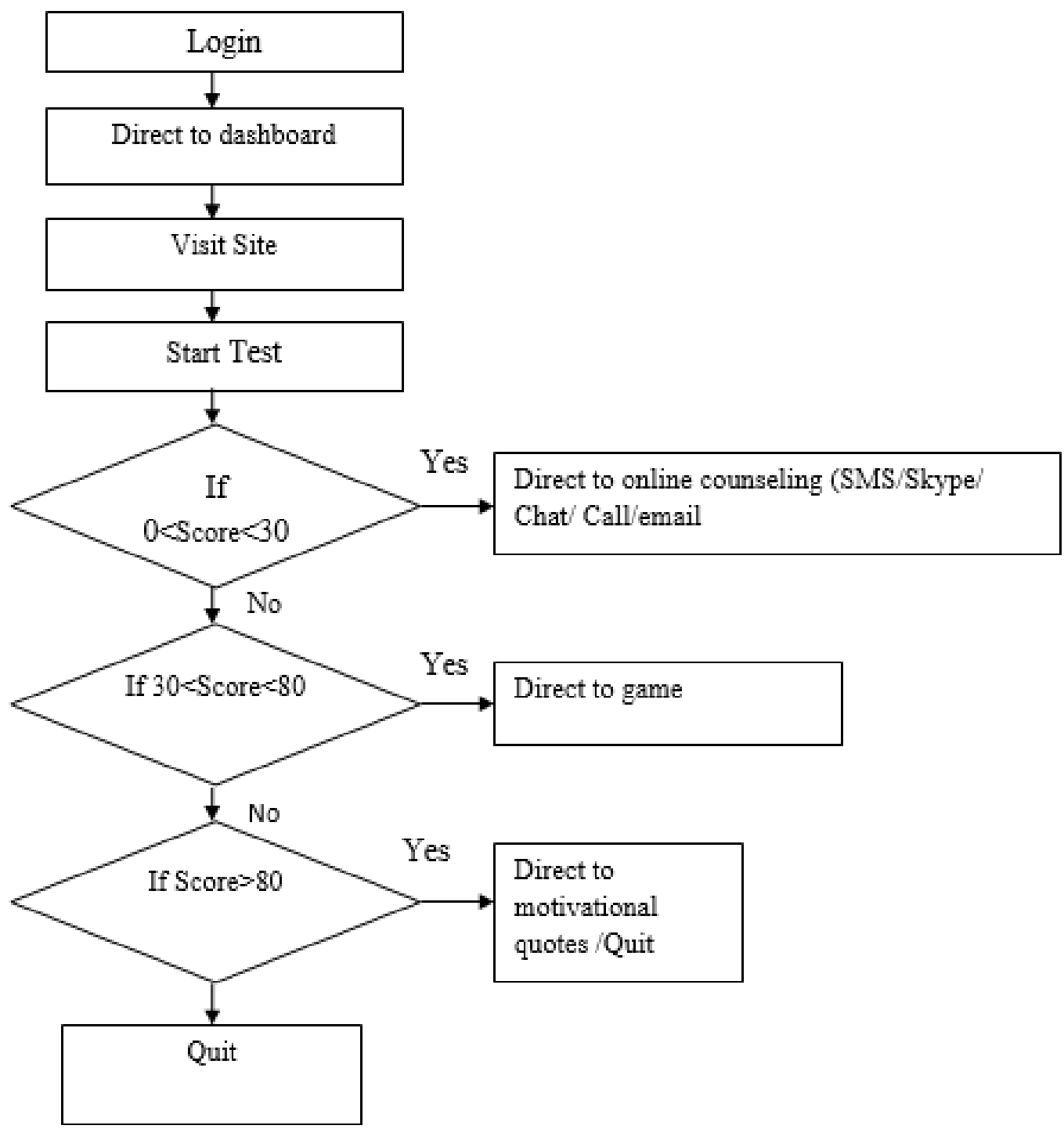

Figure 4.1.1: Major design of the online intervention 


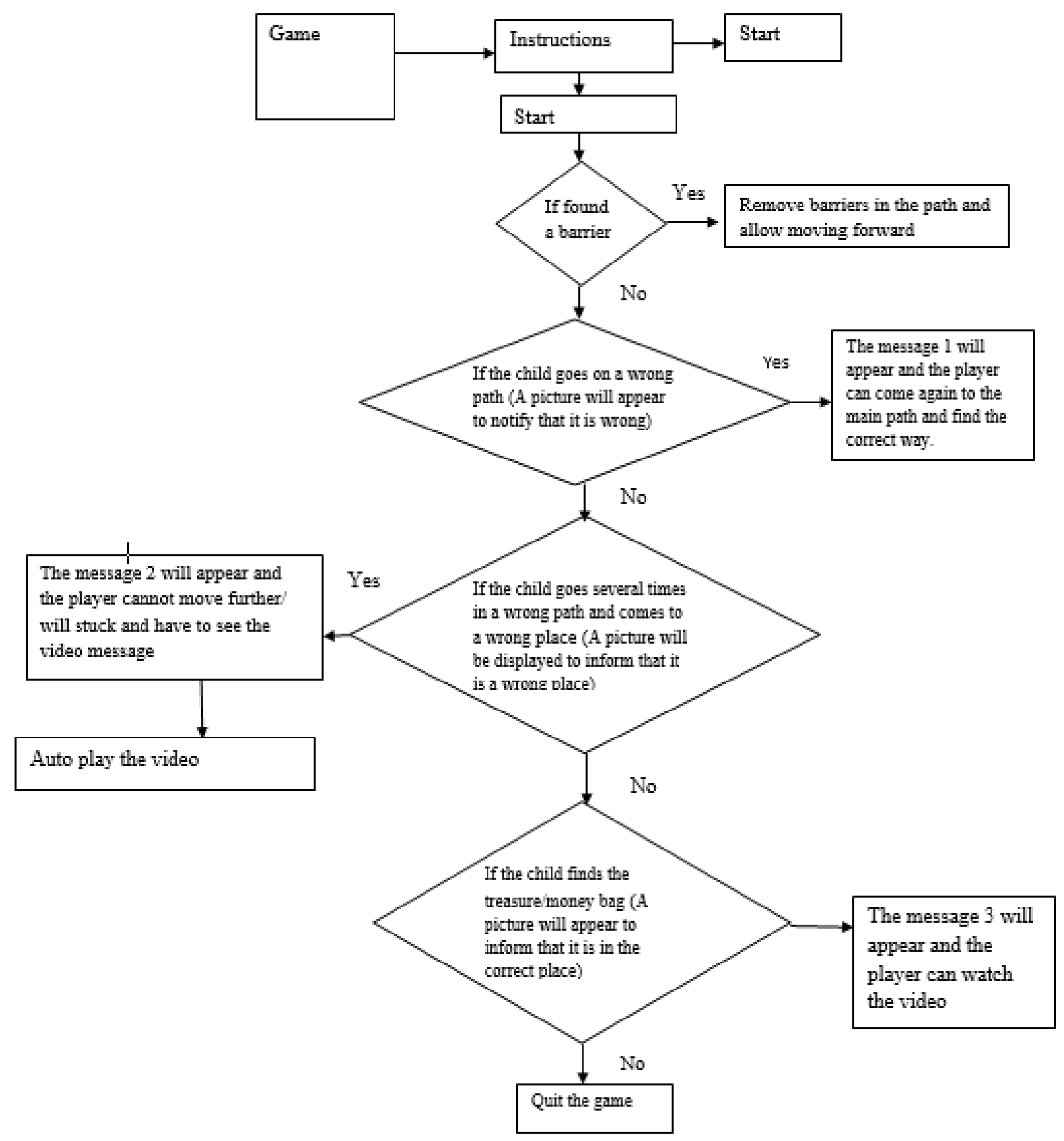

Figure 4.1.2: Design of the game 


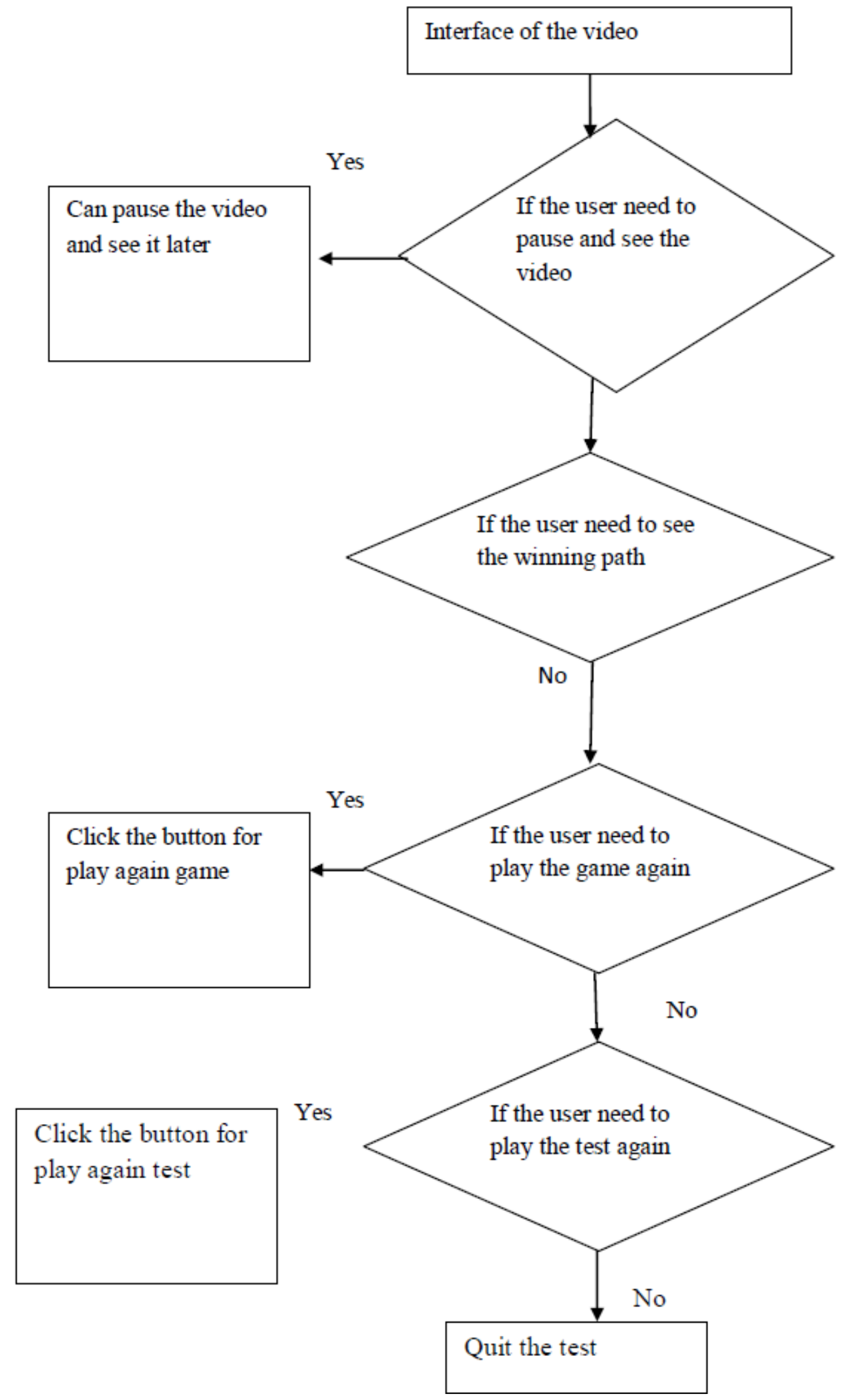

Figure 4.1.3: Design of the interface of the video 


\section{Discussion and Conclusion}

The present research aimed at answering, how ICT can be used to reduce one of the major health problems, teenage pregnancy through psychosocial competence development among teenagers. According to the literature reviews psychosocial competency is a major component in reducing adolescents' reproductive health problems and emphasizes that technology used should be flexible, interactive, and fresh. Most of the above mentioned interventions used video, game and discussion methods. Further, the results on adolescents' preferences for instructional methods revealed that video, game and discussions based learning can be considered as suitable methods for designing an online learning platform to support learning psychosocial competencies. This finding complies with the result of Péter et al.[18] who reported that video based learning is more effective than traditional methods of teaching and learning. Also, game based learning has been considered effective for creating and maintaining learners' motivation throughout the lesson [19] and discussion based learning has been found as an effective method to engage learners in deep and meaningful learning [20]. Incorporating these findings of the contemporary research, the results of the present study informs that online learning environments that are designed to support adolescents developing knowledge and skills related to psychosocial competencies may better be designed with videos, games and discussions.

\section{Acknowledgement}

We would like to express our special thanks and gratitude to all the adolescents who participated and the counselors who provided comments and evaluated our questionnaires.

\section{References}

[1] Behavior change communication strategy on reproductive health in Sri Lanka, Ministry of Health, 2015, HEO, FHB, UNFPA,

[2] Shariati, S., Fakuri, N. , Omidi M. , 2014" The Relationship between Identity Styles to Happiness and Mental Health of Students. Journal of Behavioral sciences in Asia"2(12): 86-97.

[3]Estimating the size of populations at risk for HIV: issues and methods. Arlington, VA, Family Health International, UNAIDS, WHO, 2002\

[4] Yowun sawukkya, 2000, $1^{\text {st }}$ ed, Ministry of health, WHO, UNFPA, pp. 1-38

[5] Botvin, G.J. Kantor, L. (2000). Preventing Alcohol and Tobacco Use Through Life Skills Training [pdf] [Accessed 02/04/2017]

[6] Stein, M. , 2006 , "young people leaving care,Child and Family Social Work" pp. 273-279.

[8] Eiad, Y., Rabie, N. , Anas, T. , (2015) "ICT's impact on youth and local communities in Syria"[pdf] [Accessed 02/04/2017]

[9] "TeenSource.Org: The only teen sexual health information site of its kind",2003, California Family Health Council, pp.334-445

[10] Midwest Teen Sex $\quad$ Show:wiki[Online], Available $\quad$ from< https://en.wikipedia.org/wiki/Midwest_Teen_Sex_Show > [Accessed 04/03/2017]

[11]Dahya, N, 2009,"Serious Learning in Playful Roles: Socio-political games for education and social change".

[12] DeSmet, A., Shegog, R., Van Ryckeghem, D., Crombez, G. and De Bourdeaudhuij, I., 2015. A systematic review and meta-analysis of interventions for sexual health promotion involving serious digital games. Games for health journal, 4(2), pp.78-90.

[13] Pedrana, A.E. , .Davis, R.S, Hellard, M.E., Chang, S., Howard, S., .Keogh, L, Hocking, J.S , Stoove, M.A., 2011," A systematic examination of the use of Online social networking sites for sexual health promotion".

[14]Podcasts at CDCn[Online], Available fromhttps://www2c.cdc.gov/podcasts/browse.asp?showAll=1 [Accessed 10/05/2017] 
[15] Beatty, D.I., 2014, Gaming the system: video games as a theoretical framework for instructional design, pp 1-8

[16] Engle, K.L , Vahdat, H.L. , Ndakidemi, E.,.Lasway, C.,Zan , 2012,"Evaluating feasibility, reach and potential impact of a text message family planning information service in Tanzania" vol. 87, pp 251-256

[17] Levine, D., McCright, J., Dobkin, L., Woodruff, A.J , Klausner, J.D, 2008," SEXINFO: a sexual health text messaging service for San Francisco youth", pp334-556

[18] Ngai, . W. T , Lam, and Poon. J. K. L. 2011,"Computer-supported collaborative learning system in teaching e-commerce." In Proceedings of the Thirteenth Australasian Computing Education Conference-Vol. 114, pp. 63-72. Australian Computer Society, Inc.

[19] Weerasinghe, T. A. Ramberg, R. and Hewagamage. K. P. 2012, "Inquiry-based learning with and without facilitator interactions." International Journal of E-Learning \& Distance Education 26, Vol. 2.

[20] "TeenSource.Org: 2003,The only teen sexual health information site of its kind" California Family Health Council, Vol.228, pp. 112-119,

[21] Selkie, E.M. Benson, M. Moreno, M. 2011, "Adolescents' Views Regarding Uses of Social Networking Websites and Text Messaging for Adolescent Sexual Health Education", pp. 205-212,

[22]"Children, Adolescents, and the Media", council on communications and media, 2013.

[23] Levine, D. 2009 ,"Using New Media to Promote Adolescent Sexual Health : Examples from the Field,” pp. $1-6$

[24] Free, C., Phillips, G., Galli, L., Watson, L., Felix, L., Edwads, P, Patel, V., Haines, A. , 2013, " The Effectiveness of Mobile-Health Technology-Based Health Behaviour Change or Disease Management Interventions for Health Care Consumers: A Systematic Review"pp.23-45.

[25] Lenhart,A., Kahne, J., Middaugh, E., Macgill, A., Evans, C., Vitak, J., 2008," Teens, Video Games and Civics",pp 223-334

[26] Lenhart, A.,2015, "Video Games Are Key Elements in Friendships for Many Boys"pp334-446

[27] Evers, C.W. , Albury, K. Byron, P. Craford, K. 2013," Young People, Social Media, Social Network Sites and Sexual Health Communication in Australia: "This is Funny, You Should Watch It", pp. 263-280

[28] Lenhart, A., 2009,"Teens and Social Media", pp1-8

[29] Collins, R.L, Martino, S.C., ShwRand, R.,2011, " Influence of New Media on Adolescent Sexual Health: Evidence and Opportunities",pp 1-6

[30] Yang, Z. , 2010,Encyclopedia of Cyber Behavior, pp. 250-332

[31] Sex education [Online], Available from http://pixelkin.org/2014/08/11/sex-in-gaming-sex-ed/> [Accessed 15/04/2017]

[32] Lenhart, A. , Madden , M., Smith , A. 2004, "Teens and Social Media", pp.67-98

[33] Lenhart, A., Purcell, K., Smith, A., Zickhur, K. ,2010,"Social media and mobile internet use among teens and young adults",pp556-887

[34] Strasburger, V.C., Wilson, B.J., Jordon, A.M. ,2014, "Children, Adolescents, and the Media", pp1-9

[35] Grange, D.L , Lock, J.,2011,"Eating Disorders in Children and Adolescents: A Clinical Handbook", pp. 6790

[36] Lenhart, A.,2009, "Teens and Social Media", pp1-9

[37] Engle, K.L , Vahdat H.L., Ndakidemi , E., Lasway,, Zan, T. 2012,"Evaluating feasibility, reach and potential impact of a text message family planning information service in Tanzania" vol. 87, pp 251-256 